undisclosed lobbying for a pro-Russian politician and political party in Ukraine." 36 Trump also granted a full pardon to Paul Erickson, who is the former boyfriend of Russian agent Maria Butina and was convicted of a financial crime as a result of the Mueller investigation. ${ }^{37}$

Additionally, on his last day in office, Trump pardoned Aviem Sella, an Israeli citizen who recruited former U.S. Navy intelligence analyst Jonathan Pollard to spy for Israel in the 1980s. ${ }^{38}$ The White House noted that "the Prime Minister of Israel Benjamin Netanyahu, Israeli Ambassador to the United States Ron Dermer, the United States Ambassador to Israel David Friedman, and Miriam Adelson" supported the request and that Israel "has issued a full and unequivocal apology [for its involvement], and has requested the pardon in order to close this unfortunate chapter in U.S.-Israel relations."39

Also notable are pardons Trump ultimately did not issue. In particular, Trump chose not to pardon WikiLeaks founder Julian Assange, whose extradition to the United States on espionage charges a British judge recently blocked. ${ }^{40}$ Trump also did not pardon himself, his adult children, his son-in-law Jared Kushner, his personal attorney Rudolph W. Giuliani, or participants in the January 6, 2021 riot at the U.S. Capitol building. ${ }^{41}$

\title{
INTERNATIONAL CRIMINAL LAW
}

\section{U.S. Arrest of Former Mexican Defense Minister on Drug Charges Poses Challenges for Future Counter-Narcotics Cooperation}

doi:10.1017/ajil.2021.14

In October 2020, the United States arrested former Mexican Defense Secretary General Salvador Cienfuegos Zepeda on drug conspiracy charges, accusing him of accepting bribes to aid a Mexican cartel in evading law enforcement and transporting drugs into the United

\footnotetext{
36 Trump Dec. 23, 2020 Clemency, supra note 6; Rachel Weiner, Spencer S. Hsu \& Matt Zapotosky, Paul Manafort Released from Prison, Granted Home Confinement Due to Coronavirus Fears, Wash. Post (May 13, 2020), at https:/www.washingtonpost.com/national-security/paul-manafort-granted-home-confinement-due-to-coronavirus-fears/2020/05/13/7746835c-8320-11ea-ae26-989cfce1c7c7_story.html.

37 Trump Jan. 20, 2021 Clemency, supra note 6; Maggie Haberman, Kenneth P. Vogel, Eric Lipton \& Michael S. Schmidt, With Hours Left in Office, Trump Grants Clemency to Bannon and Other Allies, N.Y. Times (Jan. 20, 2021), at https://www.nytimes.com/2021/01/20/us/politics/trump-pardons.html.

38 Trump Jan. 20, 2021 Clemency, supra note 6; Trump Pardons Israeli Officer Who Enlisted Spy Pollard, Assoc. PRESS (Jan. 20, 2021), at https://apnews.com/article/donald-trump-israel-jonathan-pollard-benjamin-netanyahuunited-states-c3d2e46029b23e7bdaa5bda6ec878247.

39 Trump Jan. 20, 2021 Clemency, supra note 6.

${ }^{40}$ Kenneth P. Vogel, With Trump Presidency Winding Down, Push for Assange Pardon Ramps Up, N.Y. Times (Jan. 10, 2021), at https:/www.nytimes.com/2021/01/10/us/politics/assange-trump-pardon.html.

${ }^{41}$ Carol D. Leonnig, Josh Dawsey \& Rosalind S. Helderman, Trump Prepares to Offer Clemency to More Than 100 People in His Final Hours in Office, WasH. POsT (Jan. 18, 2021), at https://www.washingtonpost.com/politics/ trump-pardons-final-days/2021/01/17/7a57969c-5905-11eb-a976-bad6431e03e2_story.html; Maggie Haberman \& Michael S. Schmidt, Trump Has Discussed With Advisers Pardons for His 3 Eldest Children and Giuliani, N.Y. Times (Dec. 1, 2020), at https://www.nytimes.com/2020/12/01/us/politics/rudy-giuliani-pardon.html; Alan Feuer \& Nicole Hong, "I Answered the Call of My President": Rioters Say Trump Urged Them On, N.Y. Times (Jan. 17, 2021), at https://www.nytimes.com/2021/01/17/nyregion/protesters-blamingtrump-pardon.html.
} 
States. Cienfuegos's arrest sparked diplomatic protests from Mexico, which negotiated to gain Cienfuegos's release before exonerating him and publicizing the U.S. investigation file in what the United States called a breach of the countries' mutual legal assistance treaty. The incident also prompted Mexico to pass a new law curtailing cooperation with foreign agents and potentially imperiling the long-standing U.S.-Mexico alliance in the fight against cross-border drug trafficking.

Although the U.S.-Mexico counter-narcotics partnership has undergone a number of phases, ${ }^{1}$ its most recent iteration centers around "a package of U.S. antidrug and rule of law assistance" called the Mérida Initiative, which then-Presidents George W. Bush and Felipe Calderón instituted in $2007 .^{2}$ Under the program, the United States has provided billions of dollars in security aid and support for rule-of-law institutions, ${ }^{3}$ working closely with the Mexican military and security forces to fight cross-border drug trafficking. U.S. efforts supported the Mexican government's "kingpin" strategy, which focused on "arresting (and extraditing) kingpins from each of the major drug trafficking organizations" (DTOs). ${ }^{4}$ In return for U.S. assistance, Mexico pledged to address a culture of "impunity for public corruption" within its military and law enforcement ranks that had undermined previous periods of antidrug cooperation. ${ }^{5}$

Analysts estimate that the "kingpin" strategy has had mixed success; while the effort has "incapacitated numerous top- and mid-level leaders in all the major DTOs," the fragmentation of cartel hierarchies caused by the strategy has also "contributed to violent succession struggles, shifting alliances among the DTOs, a proliferation of new gangs and small DTOs, and the replacement of existing leaders and criminal groups by even more violent ones."' Perhaps the most notable example is that of the Sinaloa Cartel, led by Joaquin "El Chapo" Guzmán Loera, which gained majority control over Mexico's drug trade after the 2008 breakup of an alliance of rival cartels "sparked the most violent period in recent Mexican history."7

The trial of Guzmán, who was extradited to the United States in 2017 and convicted on drug and murder charges in $2019,{ }^{8}$ surfaced allegations of corruption against Genaro García Luna, the former Mexican secretary of public security. ${ }^{9}$ A high-ranking Sinaloa Cartel official testified that the cartel had provided multi-million-dollar bribes to García Luna ${ }^{10}$ in exchange for, "among other things, safe passage for its drug shipments, sensitive law enforcement

\footnotetext{
${ }^{1}$ Vanda Felbab-Brown, A Dangerous Backtrack on the US-Mexico Security Relationship, BrookINGS (Dec. 21, 2020), at https://www.brookings.edu/blog/order-from-chaos/2020/12/21/a-dangerous-backtrack-on-the-usmexico-security-relationship.

${ }^{2}$ Clare Ribando Seelke, Cong. Research Serv., IF10578, Mexico: Evolution of the Mérida Initiative, 2007-2021, at 1 (2021), at https://crsreports.congress.gov/product/pdf/IF/IF10578.

${ }^{3} I d$.

${ }^{4} I d$.

${ }^{5} I d$; Felbab-Brown, supra note 1.

${ }^{6}$ June S. Beittel, Cong. Research Serv., R41576, Mexico: Organized Crime and Drug Trafficking Organizations 29 (2020), at https://crsreports.congress.gov/product/pdf/R/R41576.

${ }^{7}$ Id. at 19

${ }^{8} I d$.

${ }^{9}$ Alan Feuer, El Chapo Jury Hears About Bribes to Mexico's Public Security Secretary, N.Y. Times (Nov. 20, 2018), at https://www.nytimes.com/2018/11/20/nyregion/el-chapo-jury-hears-about-bribes-to-mexicos-public-security-secretary.html.

${ }^{10} I d$.
} 
information about investigations into the Cartel and information about rival drug cartels." 11 U.S. prosecutors indicted García Luna on December 4, 2019, ${ }^{12}$ and he has been in U.S. custody since his arrest in Dallas the following week. ${ }^{13}$

U.S. authorities arrested retired General Salvador Cienfuegos Zepeda at Los Angeles International Airport on October 16, 2020, ${ }^{14}$ pursuant to an indictment issued under seal in August 2019 in the Eastern District of New York. ${ }^{15}$ The indictment charged Cienfuegos, who had worked closely with U.S. military and law enforcement in his capacity as Mexico's secretary of national defense from 2012 to $2018,{ }^{16}$ with participation in an international conspiracy to manufacture heroin, cocaine, methamphetamine, and marijuana, to import and distribute them in the United States, and to launder the proceeds. ${ }^{17}$

In support of the government's motion for detention pending trial, acting U.S. Attorney Seth DuCharme alleged that Cienfuegos had "used his official position to assist the H-2 Cartel, a notorious Mexican drug cartel, in exchange for bribes." 18 The government alleged that Cienfuegos helped to ensure "the H-2 Cartel conducted its criminal activity in Mexico without significant interference from the Mexican military," directing enforcement resources away from H-2 and toward rival organizations. ${ }^{19}$ It accused him of assisting the cartel by, among other things, helping the group to expand its territory, "locating maritime transportation for drug shipments," and "introducing senior leaders of the H-2 Cartel to other corrupt Mexican government officials willing to assist in exchange for bribes." ${ }^{20}$ Finally, prosecutors alleged that Cienfuegos provided H-2 leaders with information about U.S. investigations into the cartel's operations - including details about government informants and cooperating witnesses, "which ultimately resulted in the murder of a member of the H-2 Cartel that . . senior leadership incorrectly believed was assisting U.S. law enforcement authorities." 21 The net effect of these actions, prosecutors alleged, was to enable "the H-2 Cartel—a cartel that routinely engaged in wholesale violence, including torture and murder - to operate with impunity in Mexico."22

Despite the gravity of the allegations, U.S. officials came under heavy pressure from their counterparts in Mexico, who objected to several facets of the investigation. In the days after

\footnotetext{
${ }^{11}$ Letter in Support of Motion to Remand at 3, U.S. v. Luna, No. 1:19-cr-00576 (E.D.N.Y. Dec. 10, 2019) (Doc. 4).

${ }^{12}$ Id. at 1.

${ }^{13}$ Mary Beth Sheridan \& Shayna Jacobs, Former Mexican Anti-drug Official Charged with Taking Bribes from "El Chapo" Cartel, Wash. Post (Dec. 10, 2019), at https://www.washingtonpost.com/world/the_americas/former-mexican-anti-drug-official-charged-with-taking-bribes-from-el-chapo-cartel/2019/12/10/b39f9e5a-1b7011ea-977a-15a6710ed6da_story.html.

${ }^{14}$ U.S. Dep't of Justice Press Release, Former Mexican Secretary of Public Security Arrested for DrugTrafficking Conspiracy and Making False Statements (Dec. 10, 2019), at https://www.justice.gov/usao-edny/ pr/former-mexican-secretary-public-security-arrested-drug-trafficking-conspiracy-and [https://perma.cc/9XR4G6KR].

${ }^{15}$ Indictment at 1, U.S. v. Zepeda, No. 1:19-cr-00366 (E.D.N.Y. Aug. 14, 2019) (Doc. 1).

${ }^{16}$ Letter in Support of Motion for a Permanent Order of Detention at 2, U.S. v. Zepeda, No. 1:19-cr-00366 (E.D.N.Y. Oct. 16, 2020) (Doc. 6).

${ }^{17}$ Indictment, supra note 15 , at $1-5$.

${ }^{18}$ Letter in Support of Motion for a Permanent Order of Detention, supra note 16, at 2.

${ }^{19} I d$. at $2-3$.

${ }^{20} \mathrm{Id}$. at 2.

${ }^{21}$ Id.at 3.

${ }^{22} I d$. at 1.
} 
the arrest, Mexican President Andrés Manuel López Obrador called on U.S. prosecutors to release their investigation files in the case, accusing the U.S. Drug Enforcement Administration of "meddling" and speculating that the arrest may have been made for "political or other reasons." ${ }^{23}$ López Obrador and other officials expressed outrage that the investigation had been conducted without the Mexican government's knowledge or cooperation, arguing that it was "not fair" for U.S. agents to investigate and build cases on Mexican soil without Mexico's input. ${ }^{24}$ Mexican Secretary of Foreign Affairs Marcelo Ebrard cast the incident as grounds for "a revision" of the U.S.-Mexico counter-narcotics partnership, ${ }^{25}$ warning that cooperation "can only exist if there is respect for Mexico's sovereignty."26

On November 17, Attorney General William Barr released a joint statement with Mexican Attorney General Alejandro Gertz Manero, announcing that the United States would request dismissal of the charges against Cienfuegos, release him to Mexico, and share its investigation file with Mexican authorities. ${ }^{27}$ The statement explained:

In recognition of the strong law enforcement partnership between Mexico and the United States, and in the interests of demonstrating our united front against all forms of criminality, the U.S. Department of Justice has made the decision to seek dismissal of the U.S. criminal charges against former Secretary Cienfuegos, so that he may be investigated and, if appropriate, charged, under Mexican law.

At the request of the Fiscalía General de la República, the U.S. Department of Justice, under the Treaty that governs the sharing of evidence, has provided Mexico evidence in this case and commits to continued cooperation, within that framework, to support the investigation by Mexican authorities.

Our two countries remain committed to cooperation on this matter, as well as all our bilateral law enforcement cooperation. As the decision today reflects, we are stronger when we work together and respect the sovereignty of our nations and their institutions. This close partnership increases the security of the citizens of both our countries. ${ }^{28}$

In support of the government's motion to dismiss the indictment, acting U.S. Attorney DuCharme explained that "sensitive and important foreign policy considerations outweigh the government's interest in pursuing the prosecution" of Cienfuegos. ${ }^{29}$ He noted that, "in recognition of the strong law enforcement partnership between Mexico and the United

${ }^{23}$ Kevin Sieff, Mary Beth Sheridan \& Missy Ryan, U.S. Arrest of Former Mexican Defense Chief Tests Anti-Drug Alliance, WASH. POST (Oct. 24, 2020), at https://www.washingtonpost.com/world/the_americas/mexico-drugscartels-cienfuegos/2020/10/24/29fbd5ce-12f5-11eb-bc10-40b25382f1be_story.html.

${ }^{24}$ Alan Feuer \& Natalie Kitroeff, Mexico, Outraged at Arrest of Ex-official, Threatened to Toss U.S. Agents, N.Y. TimES (Nov. 18, 2020), at https://www.nytimes.com/2020/11/18/world/americas/mexico-cienfuegos-barr.html.

${ }^{25} \mathrm{Id}$.

${ }^{26}$ Kevin Sieff, Mary Beth Sheridan \& Matt Zapotosky, U.S. Agrees to Drop Charges Against Former Mexican Defense Minister, WASH. Post (Nov. 17, 2020), at https://www.washingtonpost.com/world/the_americas/ mexico-cienfuegos-drug-charges-dropped/2020/11/17/430bd056-291f-11eb-92b7-6ef17b3fe3b4_story.html.

${ }^{27}$ U.S. Dep't of Justice Press Release, Joint Statement by Attorney General of the United States William P. Barr and Fiscalía General of Mexico Alejandro Gertz Manero (Nov. 17, 2020), at https://www.justice.gov/opa/pr/ joint-statement-attorney-general-united-states-william-p-barr-and-fiscal-general-mexico [https://perma.ccl A2TK-7BHE].

${ }^{28} \mathrm{Id}$.

${ }^{29}$ Motion to Dismiss at 1, U.S. v. Zepeda, No. 1:19-cr-00366 (E.D.N.Y. Nov. 16, 2020) (Doc. 20). 
States, and in the interests of demonstrating our united front against . . the trafficking of narcotics by Mexican cartels," the United States sought to have the charges dismissed "in order to permit the Mexican investigation and potential prosecution of the defendant to proceed in the first instance." 30 In granting the government's motion to dismiss, U.S. District Judge Carol Bagley Amon deferred to the Trump administration's "determination that the Mexican prosecuting authorities sincerely wish to pursue an investigation and prosecution" of Cienfuegos. ${ }^{31}$ Democratic Senator Bob Menendez, then-ranking member of the Senate Foreign Relations Committee, released a statement accusing the Trump administration of "turning a blind eye to the facts and selling out U.S. national security interests," arguing that the U.S.-Mexico relationship "must be built on common respect for our own rule of law and due process." 32

As soon as Cienfuegos was released, Mexican President López Obrador cast doubt on Mexico's willingness to prosecute, saying, "There is no impunity for anyone, but at the same time crimes will not be allowed to be fabricated." $33 \mathrm{He}$ framed the case as a referendum on "the prestige of a fundamental institution of the Mexican state," and pledged not to allow the armed forces to be "undermin[ed]" without evidence. ${ }^{34}$

On January 14, 2021, Mexico cleared Cienfuegos of all charges, claiming that its own review of the "essential evidence" refuted every allegation levied by U.S. prosecutors:

[I]t was concluded that General Salvador Cienfuegos Zepeda never had any encounter with the members of the criminal organization investigated by the North American authorities; nor did he maintain any communication with them, nor did he carry out acts aimed at protecting or helping said individuals. ${ }^{35}$

A day later, Mexico's attorney general moved to release the U.S. investigative file to the public, deeming it "appropriate to strengthen the rule of law and the principles of transparency and justice." 36 López Obrador applauded the decision to publicize the case file, casting it as a victory for "full transparency" and citing it as evidence of his administration's resolve to fight corruption and "impunity." ${ }^{37} \mathrm{He}$ delivered a warning to foreign officials seeking to

${ }^{30}$ Id. at 3.

${ }^{31}$ Kevin Sieff \& Shayna Jacobs, Mexico Welcomes U.S. Release of Accused Former Defense Minister, but Episode Has Deepened Mistrust on Both Sides, WASH. PoST (Nov. 18, 2020), at https://www.washingtonpost.com/world/the_americas/mexico-cienfuegos-drug-charges-dropped/2020/11/18/a0fbe724-29af-11eb-8fa2-06e7cbb145c0_story.html.

32 Office of Sen. Robert Menendez Press Release, Menendez Reaction to Trump Administration's Retreat on Drug Trafficking Case Against Former Mexican Defense Minister (Nov. 18, 2020), at https://www.foreign.senate.gov/press/ranking/release/menendez-reaction-to-trump-administrations-retreat-on-drug-trafficking-caseagainst-former-mexican-defense-minister [https://perma.cc/UD8F-FAZE].

${ }^{33}$ Sieff \& Jacobs, supra note 31.

${ }^{34} I d$.

${ }^{35}$ Mexican General Prosecutor of the Republic Press Release, FGR Determines Not to Exercise Criminal Action in Favor of General Cienfuegos (Jan. 14, 2021), at https://www.gob.mx/fgr/prensa/comunicado-fgr013-21-fgr-informa (unofficial translation from Spanish to English).

${ }^{36}$ Mexican General Prosecutor of the Republic Press Release, Case File of Salvador C. (Jan. 15, 2021), at https://www.gob.mx/fgr/documentos/investigacion-cienfuegos (unofficial translation from Spanish to English).

${ }^{37}$ Mexican Presidency of the Republic Press Release, Federal Executive Supports FGR Decision Regarding Cienfuegos Case, Says President, (Jan. 15, 2021), at https://www.gob.mx/presidencia/prensa/ejecutivo-federalrespalda-decision-de-fgr-en-torno-al-caso-cienfuegos-afirma-presidente (unofficial translation from Spanish to English). 
investigate Mexican officials without the government's consent: "[A]bove all else is the prestige of our nation and we cannot be held hostage by anyone." 38

In a statement, the U.S. Justice Department said:

We are deeply disappointed by Mexico's decision to close its investigation of former Mexican Secretary of National Defense General Salvador Cienfuegos Zepeda. The United States Department of Justice fully stands by its investigation and charges in this matter.

The United States Department of Justice is also deeply disappointed by Mexico's decision to publicize information shared with Mexico in confidence. Publicizing such information violates the Treaty on Mutual Legal Assistance between Mexico and the United States, and calls into question whether the United States can continue to share information to support Mexico's own criminal investigations.

Finally, the United States Department of Justice notes that the materials released by Mexico today show that the case against General Cienfuegos was, in fact, not fabricated. Those materials also show that the information relied upon to charge General Cienfuegos was lawfully gathered in the United States, pursuant to a proper U.S. court order, and in full respect of Mexico's sovereignty. A U.S. federal grand jury analyzed that material and other evidence and concluded that criminal charges against Cienfuegos were supported by the evidence. ${ }^{39}$

The Cienfuegos affair has touched off a broader conversation about the future of the U.S.Mexico counter-narcotics partnership. Contemporaneous media accounts cite a Mexican threat to expel all Drug Enforcement Administration agents from the country as a major impetus for the U.S. decision to release Cienfuegos in November. ${ }^{40}$ A few weeks later, however, López Obrador sent a bill to the Mexican legislature that would require Mexican officials to get permission before working with "foreign agents" and provide detailed reports of all meetings to the Foreign and Public Security Ministries_-requirements that analysts speculate could lead to security risks for U.S. agents and increased corruption within the Mexican security state. ${ }^{41}$ Attorney General Barr released a statement arguing that the law

would have the effect of making cooperation between our countries more difficult. This would make the citizens of Mexico and the United States less safe. The passage of this

${ }^{38} I d$.

${ }^{39}$ U.S. Department of Justice - International (@ USDOJ_Intl), TwITTER (Jan. 16, 2021, 12:34 PM), at https:// twitter.com/USDOJ_Intl/status/1350496611517026306. See also Kate Linthicum, U.S. Rebukes Mexico for Releasing Evidence in Drug Case Against Former Defense Minister, L.A. TimEs (Jan. 16, 2021), at https://www.latimes.com/world-nation/story/2021-01-16/u-s-rebukes-mexico-evidence-drug-case-former-defense-minister; Mary Beth Sheridan, López Obrador Lashes Out at DEA After Mexico Exonerates Ex-minister on Drug Charges, WASH. PosT (Jan. 15, 2021), at https://www.washingtonpost.com/world/amlo-attacks-dea-salvador-cienfuegosmexico-defense-minister/2021/01/15/3f6aad0c-573f-11eb-acc5-92d2819a1ccb_story.html.

${ }^{40}$ Feuer \& Kitroeff, supra note 24.

${ }^{41}$ Mary Beth Sheridan, Mexico Fast-Tracks Law that Could Limit Anti-drug Cooperation with U.S., WaSH. POST (Dec. 11, 2020), at https://www.washingtonpost.com/world/the_americas/mexico-fast-tracks-law-that-couldlimit-antidrug-cooperation-with-us/2020/12/11/aa2f90d4-3b43-11eb-98c4-25dc9f4987e8_story.html. 
legislation can only benefit the violent transnational criminal organizations and other criminals that we are jointly fighting. ${ }^{42}$

When the law passed in December 2020, officials across the Mexican government hailed it as a victory for Mexican sovereignty and local control in the war on drugs. ${ }^{43}$ López Obrador suggested the move simply put Mexico on an equal footing with other countries—including the United States - that seek to exercise control over foreign agents operating on their soil. ${ }^{44}$

Although the bill's full impact remains to be seen, it portends challenges in the U.S.Mexico anti-drug partnership. Due to a protracted turf war between the major cartels, the Mexican security situation has deteriorated; a Central Intelligence Agency study estimates that as much as twenty percent of Mexico's territory may be under the effective control of DTOs. ${ }^{45}$ López Obrador was one of the last world leaders to congratulate Biden on his election victory, ${ }^{46}$ and figures within his Morena party have been open about their desire to roll back cooperation with the United States in the drug war. ${ }^{47}$ Shortly after Cienfuegos's release, Mexico requested the extradition of former public security minister Genaro García Luna, raising the specter that it may begin to exert similar diplomatic pressure against the United States in future conflicts over counter-narcotics and anti-corruption policies. ${ }^{48}$

\section{IMMIGRATION AND MigRATION}

\section{Biden Administration Reverses Trump Administration Policies on Immigration and Asylum} doi:10.1017/ajil.2021.15

After taking office, the Biden administration quickly moved to reverse or revoke a number of the Trump administration's immigration-related policies. On inauguration day, President Joseph Biden announced several significant changes, including termination of the national emergency at the southern border, halting border wall construction, and removal of discriminatory travel restrictions imposed primarily on Muslim-majority countries. In the following

42 U.S. Dep't of Justice Press Release, Statement by Attorney General William P. Barr on Mexico's Proposed Legislation (Dec. 11, 2020), at https://www.justice.gov/opa/pr/statement-attorney-general-william-p-barr-mexicos-proposed-legislation [https://perma.cc/AJG8-EVB2].

43 See Sheridan, supra note 41 (quoting officials who argued the foreign agent law will allow Mexico to establish "a harmonious relationship with the United States" on anti-drug efforts, "but not one of subordination").

${ }^{44}$ Oscar Lopez, Mexico, in Rebuke to U.S., Adopts Measure Restricting Foreign Agents, N.Y. TimEs (Dec. 15, 2020), at https://www.nytimes.com/2020/12/15/world/americas/mexico-us-drug-agents.html.

${ }^{45}$ Mary Beth Sheridan, Violent Criminal Groups Are Eroding Mexico's Authority and Claiming More Territory, WASH. POST (Oct. 29, 2020), at https:/www.washingtonpost.com/graphics/2020/world/mexico-losing-control/ mexico-violence-drug-cartels-zacatecas.

${ }^{46}$ Lopez, supra note 44.

${ }^{4}$ See Mary Beth Sheridan, Mexico Lashes Out at U.S. with Law Expected to Harm Cooperation on Drug Fight, WASH. PosT (Dec. 15, 2020), at https://www.washingtonpost.com/world/the_americas/mexico-drug-traffickingdea-amlo/2020/12/15/fea76612-3e47-11eb-8bc0-ae155bee4aff_story.html. A congresswoman in López Obrador's party attacked the U.S.-led Mérida Initiative before stating: "We don't have to subordinate ourselves to the decisions of any other country, as prior governments did." Id.

${ }^{48}$ Mexico Asks US to Extradite Country's Former Security Chief, Assoc. Press (Dec. 7, 2020), at https://apnews. com/article/mexico-trials-arrests-united-states-crime-41421287c8c8cffd95b23827ce7cec03. 